\title{
The European Illustrated Press
}

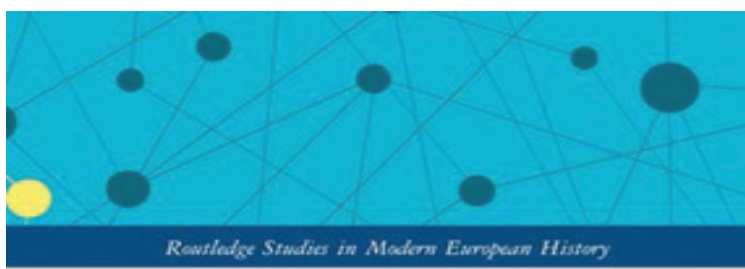

THE EUROPEAN

ILLUSTRATED PRESS AND

THE EMERGENCE OF A

TRANSNATIONAL VISUAL

CULTURE OF THE NEWS,

1842-1870

Thomas Smits

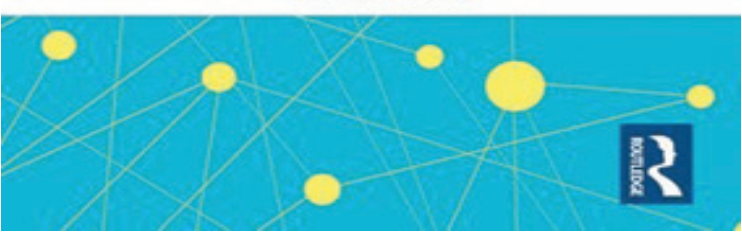

\section{Thomas Smits}

The European Illustrated Press and the Emergence

of a Transnational Visual Culture of the News,

1842-1870

(London: Routledge, 2020), 240 pp.

isbn 978-0-429-28438-0

\section{Reviewed $b y$ \\ Anne Hultzsch is Senior Lecturer in Architecture \\ Histories and Theories at University of Greenwich.}

The Illustrated London News 'will pour the lore of the Antiquarian into the scholar's yearning soul and teach him truth about those who have gone before him, as it were, with the Pictorial Alphabet of Art!'1 Thus wrote the editors of the world's first illustrated newspaper upon publishing their first annual bound volume filled with several months' worth of lavish images. Obligingly, scholars have followed this call, and since the mid twentieth century at least, pored over pages and pages full of illustrations and accompanying texts depicting the world as seen through the eyes of someone wanting to profit from selling the world as it appeared from Britain. One of the most captivating features of the mid-nineteenth century illustrated press was perhaps its own appreciation of its global and historical significance. As Thomas Smits shows in The European Illustrated Press and the Emergence of a Transnational Visual 
Culture of the News, 1842-1870, this significance went far beyond the realms of any one nation or empire.

In his meticulously researched and methodologically rigorous study, Smits argues that the 'dissemination of popular illustrated newspapers and their images led to the formation of a transnational visual culture of the news in the nineteenth century' (218). He takes the concept of transnational history from Jürgen Osterhammel who has recently been instrumental in the transnational turn within the social sciences. ${ }^{2}$ Identifying an image trade across national and continental borders, giving birth to what would eventually become a 'global visual news culture', Smits expands histories of rising nationalisms and of national identity in the period. Rather than differentiating nations and their common knowledge bases, he shows that European (and European-influenced) nineteenth-century culture became aligned and levelled up (or down).

Smit's volume opens with a survey of the geographies of the reader (ranging from urban to national, colonial and international) of the three protagonists among the illustrated newspapers, the Illustrated London News, the Illustrirte Zeitung, and l'Illustration. As in other studies, his focus is often on Britain, the self-declared leader in the business of illustrated news. He includes the view back from the colonies, especially Australia and New Zealand, noting how the image of the mother country was as important to the colonists as it was to those back home. Knowing that those at the other side of the world viewed the same picture and read the same news, contributed to a national feeling of belonging that could cross continental borders. In the second chapter, Smits traces the transnational trade in illustrations, pointing out that as prices per illustration tended to decrease during the period of investigation, the economic entanglement of titles from different countries increased. In a well-argued chronology, Smits identifies three stages of the European illustrated newspaper between 1842 and 1870: first, the supremacy of the Illustrated London News (as expected by its editors from the start) up to around 1850; followed by a decade in which the triumvirate of Illustrated London News, the Illustrirte Zeitung and l'Illustration published and then fed illustrations to their smaller imitations across Europe; succeeded in turn by a wave of cheaper penny papers recycling illustrations again to reach less affluent strata of society. This was achieved through a tight network of publishers, editors and, crucially, engraving firms. Smits attests that an intricate transnational web of illustrated newspapers' existed across Europe already in the 1840s (117). Disappointingly, he does not attempt to trace the effect this had on contemporary events or trends; for instance, one wonders whether the revolutions that spread across the continent in this decade were spurred by this capitalist drive to exploit the hunger for information? Alternatively, veering into my own field, what was the effect of the new transnational visual literacy on visual cultures outside of the printed image, on painting, architecture, or literature? 
Chapter 3 of Smits' book promises a close analysis of the way in which Cassel's Illustrated Family Paper, which surpassed even the Illustrated London News in its distribution, bought and reproduced images from l'Illustration showing scenes from the Crimean War. While textual elements were adapted for its British audience, Cassel's contributed, so goes Smits' argument, to the formation of 'transnational viewers' (131), as both French and British readers consumed the same images. Smits' reasoning for this is perhaps self-evident: as Cassell wanted to sell his newspaper in Britain, he strove to please the British, not the French. Significantly, this whole chapter is based on physical archival research, as Cassel's is not digitised, in sharp contrast to the Illustrated London News, the Illustrirte Zeitung and l'Illustration. Here, a particular quality of the book becomes evident: the rigorous openness about how sources were consulted, whether in hardcopy or digitally (even listing the search terms for keyword searches conducted in specific online databases). It transpires that while the nineteenth-century newspaper reader turned into the transnational viewer, so is the twentyfirstcentury historian becoming the digitally enabled transnational researcher. Smits' referencing is exemplary, and it is to be hoped that many scholars will follow the standard he has set. While Smits gives credit to both forms of research, digital and paper-based, he ascribes the latter with a more immersive nature. While many scholars have remarked on it, there seems to be scope for more reflection on the effect of the materiality (if any) of the archive on the historiography of print media and the ways historians give credits to the archival medium. The closing chapter of the book investigates the representation of the Paris Universal Exhibition of 1867 in European and American illustrated newspapers. Linking world exhibitions as 'mass events' to mass media (209), Smit concludes that, 'for the first time in history, millions of readers started looking at the same world' (14). Echoing Patricia Anderson's earlier claim that already the Penny Magazine by the 1830s had set the 'first foundations of what would eventually become a "global village"', Smit successfully shows us that many of our news consumption habits were born in a pre-digital, pre-photography age. ${ }^{3}$ As Beatriz Colomina has argued that modern architecture became modern only in it engagement with the mass media, the mass media were born from an engagement with - themselves. ${ }^{4}$ Selling, buying and reproducing images, at times reframing and contextualising them through text, they gave readers the impression that seeing implied knowing. Ultimately they contributed to a form of globalization which excluded large parts of the world while seemingly bringing others closer together - all for the sake of selling the commodity of the news.

\section{Notes}

1. “Preface," The Illustrated London News (London: William Little, 1842), i. 
2. Jürgen Osterhammel, "A Transnational History of Society. Continuity or New Departure?," in Comparative and Transnational History: Central European Approaches and New Perspectives, ed. Heinz-Gerhardt Haupt and Jürgen Kocka (New York: Berghahn Books, 2009), 39-52.
3. Patricia J. Anderson, The Printed Image and the Transformation of Popular Culture, 1790-1860 (Clarendon Press, 1991), 198.

4. Beatriz Colomina, Privacy and Publicity: Modern Architecture as Mass Media (Cambridge, Mass.: MIT Press, 1994).

TMG Journal for Media History

Volume 24 No (1/2)/2021

DOI

https://dx.doi.org/10.18146/tmg.799

\section{PUBLISHER}

Netherlands Institute for Sound and Vision

\section{COPYRIGHT}

Each article is copyrighted (c) by its author(s) and is published under license from the author(s). When a paper is accepted for publication, authors will be requested to agree with the Creative Commons Attribution 4.0 International License. 